University of Wollongong

Research Online

Faculty of Engineering - Papers (Archive)

Faculty of Engineering and Information

Sciences

7-6-2006

\title{
Acid sulphate soil remediation techniques on the Shoalhaven River Floodplain, Australia
}

Buddhima Indraratna

University of Wollongong, indra@uow.edu.au

A. N. Golab

University of Wollongong, golab@uow.edu.au

W. Glamore

University of New South Wales

B. Blunden

BHP Billiton

Follow this and additional works at: https://ro.uow.edu.au/engpapers

Part of the Engineering Commons

https://ro.uow.edu.au/engpapers/308

\section{Recommended Citation}

Indraratna, Buddhima; Golab, A. N.; Glamore, W.; and Blunden, B.: Acid sulphate soil remediation techniques on the Shoalhaven River Floodplain, Australia 2006.

https://ro.uow.edu.au/engpapers/308

Research Online is the open access institutional repository for the University of Wollongong. For further information contact the UOW Library: research-pubs@uow.edu.au 


\title{
Acid sulphate soil remediation techniques on the Shoalhaven River floodplain, Australia
}

\author{
B. Indraratna1, A. Golab², W. Glamore ${ }^{3} \&$ B. Blunden ${ }^{4}$ \\ ${ }^{1}$ Professor of Civil Engineering, University of Wollongong, Wollongong, NSW 2522, Australia \\ (e-mail: indra@uow.edu.au) \\ ${ }^{2}$ Faculty of Engineering, University of Wollongong, Wollongong, NSW 2522, Australia \\ ${ }^{3}$ Water Research Laboratory, University of New South Wales, Sydney, NSW 2000, Australia \\ ${ }^{4}$ New South Wales Department of Environment and Conservation, Wollongong, NSW 2500, Australia
}

\begin{abstract}
A commonly used flood mitigation technique in coastal areas of Australia during the late 1960s was the installation of one-way floodgates on flood mitigation drains. In regions affected by acid sulphate soils (the oxidation of pyrite in the soil forms sulphuric acid), the floodgates prevent tidal carbonate/ bicarbonate buffering of the drains and thereby create reservoirs of acidic water $(\mathrm{pH}<4.5)$ that discharge during low tide. Several acid sulphate soil remediation techniques have been used in coastal lowland in southeastern NSW, Australia. Following extensive monitoring and finite element modelling of groundwater conditions and quality, fixed level V-notch weirs were installed at three elevations to maintain elevated groundwater levels. The weirs successfully maintained the groundwater level above the acid sulphate soils, preventing additional pyrite oxidation, and reduced the rate of discharge of acid to the drain. Following further monitoring, investigation into anaerobic acid sources, and finite element-based geochemical modelling, modified two-way floodgates that allow tidal ingress were installed. The modified floodgates were successful in buffering the drain water $\mathrm{pH}$ before discharging the drain water into adjacent waterways. Numerical analysis based on finite element modelling was extended to illustrate that saline intrusion into the surrounding soil (as a result of tidal ingress and acid buffering in the drains) was not a major concern for the pastureland or other agricultural activities.
\end{abstract}

Keywords: acid sulphate soils, remediation, tidal buffering, finite element modelling

Acidification of coastal waterways is a well-recognized environmental, economic and social problem in Australia that requires urgent attention (Indraratna \& Blunden 1999). Soils that contain iron sulphides are commonly referred to as acid sulphate soils (ASS). Pyrite is the dominant iron sulphide in coastal NSW and it formed during the last major interglacial. If left undisturbed and submerged by groundwater the pyrite is chemically inert; however, when the groundwater falls below the elevation of the sulphidic soil horizon, atmospheric oxygen is able to diffuse through overlying soil layers and the pyrite oxidizes to form sulphuric acid.
The acid in turn mobilizes iron and aluminium ions into the groundwater, leading to even greater environmental problems. White et al. (1997) provide a conservative estimate of the extent of acid sulphate soils in Australia at 3 million hectares.

The use of deep flood mitigation drains causes major problems in regions affected by ASS (Sammut et al. 1994). The channelized, high-density drainage systems in low-lying coastal areas have greatly increased the rate of lateral water outflow, resulting in a lowering of the water table below its natural position. The entrainment of air (oxygen) is rapid in the drained upper soil layers caused by old root channels, weathering, desiccation, and soil disturbance by agricultural activity. Hence, through causing drawdown of the surrounding groundwater, one-way floodgates expose pyrite to oxidizing conditions (Fig. 1). One-way floodgates are commonly fitted to flood mitigation drains (Williams \& Watford 1997). The one-way flap valves discharge the drain water into the nearby waterway at low tide but prevent the entry of water from the waterway at high tide, thus restricting the process of tidal carbonate/bicarbonate buffering. The ensuing drain water attacks concrete infrastructure, clogs waterways with iron flocculates and kills fish due to the high iron and aluminium content of the water. In addition, the pastureland overlying the ASS becomes unsuitable for growing deep-rooted plants. As a result, coastal estuaries and floodplains can become severely acidified, leading to a loss of agricultural and fishery productivity and damage to steel and concrete infrastructure.

If dry conditions dominate, then evapotranspiration from the groundwater can lower the water table further, giving rise to very large volumes of sulphidic soil exposed to oxidizing conditions. When the groundwater is recharged by rainfall, the acidic oxidation products that were generated when the groundwater table was below the sulphidic soil layer can be transported to the drains (Indraratna et al. 2001). In order to reduce the oxidation of pyrite, the availability of oxygen must be reduced. The diffusion of oxygen through water is about $10^{5}$ times slower than through air. Therefore, a potential method of reducing oxygen transport to the pyritic layer is to maintain high groundwater levels above the elevation of the potential acid sulphate soil, for example through the use of weirs (Blunden \& Indraratna 2000). 

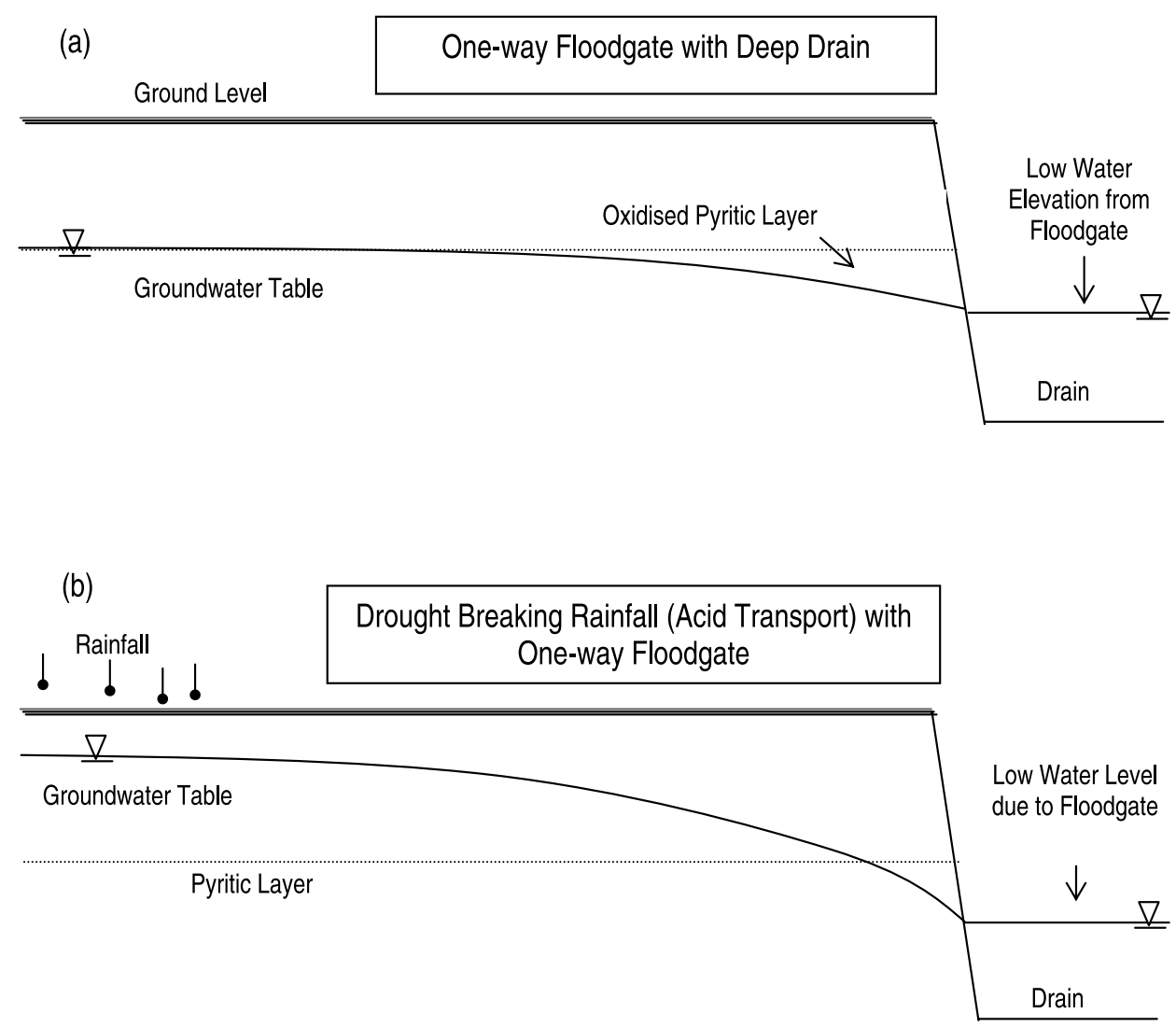

(c)

Tidal Intrusion via Modified Floodgate

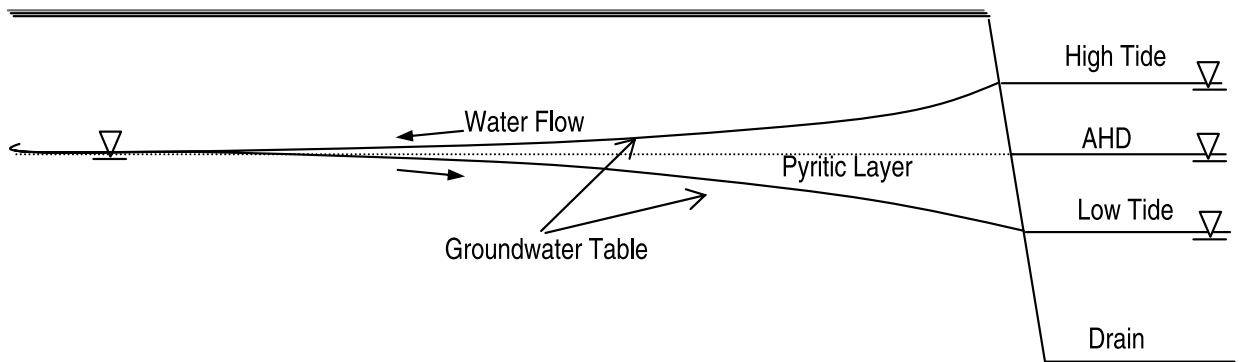

Fig. 1. Groundwater elevation and transport as influenced by one-way floodgates (a), heavy rain (b), and tidal intrusion (c) (adapted from Indraratna et al. 2002). AHD is Australian Height Datum.

Manipulation of the groundwater table is also utilized in the management of sulphidic tailings that would otherwise oxidize to form acid rock drainage. Complete inundation of acid-producing materials has been successful in decreasing the oxidation of tailings in areas where the water table may be re-established to submerge the materials in lakes or other permanent impoundments (Pedersen 1983). However, if only a shallow cover is used, for example $0.3 \mathrm{~m}$, the tailings may oxidize because wind creates turbulence that increases the dissolved oxygen content (Yanful \& Verma 1999; Vigneault et al. 2001).
Carbonate/bicarbonate buffering, or tidal buffering, is based on the concept that incoming tides transport acid buffering agents throughout an estuary. The major buffering constituents of seawater are bicarbonate $\left(\mathrm{HCO}_{3}{ }^{-}\right)$and carbonate $\left(\mathrm{CO}_{3}{ }^{2-}\right)$. Substantial improvements in water quality have been reported when leakage of one-way floodgates allows tidal buffering within acid-affected flood mitigation drains (e.g. Blunden 2000). Allowing tidal flushing into flood mitigation drains via modified floodgates may: (i) decrease the 'acid reservoir effect', (ii) increase dissolved oxygen levels, (iii) decrease the hydraulic gradient between the drain 
and groundwater, (iv) diminish aluminium flocculation, (v) combat exotic freshwater weeds, (vi) enhance runoff during wet periods, and (vii) allow fish passage into important breeding grounds (Pollard \& Hannan 1994; Portnoy \& Giblin 1997; Dick \& Osunkoya 2000; Glamore \& Indraratna 2001; Indraratna et al. 2002; Glamore 2003).

The restoration of tidal influx via modified floodgates is a well-documented means of improving the geochemical, hydrodynamic and acid transport conditions within acid sulphate soil affected drains (Sutherland et al. 1996; Indraratna et al. 2002; Johnston et al. 2002). The effectiveness of the tidal buffering would depend on a number of factors including the concentration of buffering agents, the acid concentration, and the hydrodynamics and salinity regime of the estuary. The use of tidal flows within flood mitigation drains via modified floodgates is a complex and potentially high-risk procedure. If careful management is not conducted, tidal inflows may overtop the drain levee bank causing inundation of low-lying floodplains with saline or brackish water. To predict the potential impact of restoring tidal inflows to an acidic flood mitigation drain, a range of water quality conditions must be considered.

The mechanisms of carbonate/bicarbonate buffering are well established (Stumm \& Morgan 1996) but no long-term studies have been conducted on acid sulphate soil drainage. The main method previously used for determining the potential impacts of tidal influx involves short-term floodgate openings and sandbagging of suspected overtopping hotspots. This method is timeintensive, basic and, due to the short period of floodgate opening, may not represent long-term environmental ramifications (Johnston et al. 2002) or the full range of water quality and tidal conditions likely to occur after floodgate modifications.

This paper outlines the remediation techniques that have been used at a study site in southeastern NSW. These include the use of fixed level V-notch weirs to maintain the groundwater level above the pyrite layer, hence preventing the oxidation of pyrite. Another remediation technique that has been implemented is the use of modified floodgates that open in both directions to allow the ingress of tidal water and thus the buffering of acidity. The further benefit of the two-way floodgates is that tidal inflow may increase the drain water elevation, thus reducing pyrite oxidation and acid transport.

\section{Study site}

The study site is a small subcatchment, approximately 120 ha of coastal lowland adjacent to the township of Berry $\left(34^{\circ} \mathrm{S}, 150^{\circ} \mathrm{E}\right)$ on the south coast of New South Wales, Australia (Fig. 2). In the late 1960s, deep flood mitigation drains (approximately $3.5 \mathrm{~m}$ deep $\times 8 \mathrm{~m}$ wide) were installed through the pastureland to minimize the risk of flooding and increase surface runoff. One-way, top-hinged flap gates are located at the mouth of most drains to inhibit tidal intrusion and maintain low drain water elevations. The drains discharge at low tide into Broughton Creek, a tributary of the Shoalhaven River.

The site is typical of coastal floodplains in NSW with a maximum elevation of $4 \mathrm{~m}$ and a minimum elevation of $<1 \mathrm{~m}$ relative to the Australian Height Datum (AHD). Sulphidic sediments, formed during the Holocene, are covered with shallow layers of alluvium approximately 1.3 to $1.4 \mathrm{~m}$ deep. The network of relatively deep drains has lowered the water table, exposing the sulphidic layers even during mild drought conditions. This study site was chosen because of the threat of serious acid pollution of Broughton Creek. The primary drains in the area are fed by acidic groundwater drainage, while several secondary feeder drains also transport highly acidic surface water $(\mathrm{pH}<3.0)$ from the surrounding floodplain.

\section{Groundwater level adjustment using weirs}

\section{Research approach}

At the centre of remediation or management strategies for coastal acid sulphate soils is the calculation of the amount of acid produced in the soil matrix by pyrite oxidation. Considerable research into modelling the oxidation of pyrite has been performed. A new theoretical approach for simulating the transport of oxygen into a macropore-structured acid sulphate soil and the subsequent diffusion of oxygen laterally into the soil matrix has been discussed elsewhere (Blunden \& Indraratna 2001). The results of this model were used for the management strategies discussed in this paper.

The first management strategy that was considered was the use of fixed level weirs to increase the height of the groundwater table to fully saturate the pyritic soil layer, thus preventing further pyrite oxidation. Firstly, finite element analysis, using PC-SEEP and FEMWATER (originally developed by Lin et al. 1997), was used to estimate the effect that raising the drain water level would have on the depth of the groundwater table. When the drain level was modelled at a maximum depth of $0.5 \mathrm{~m}$ below the ground surface, a large percentage of the ASS layer was submerged beneath the water table (Blunden et al. 1997). Further modelling using a series of hydrologic and hydraulic procedures revealed that the installation of weirs would allow the groundwater table to rise to a specific level without causing flooding of the pastureland. Finally, it was decided to use weirs in the flood mitigation drains. 


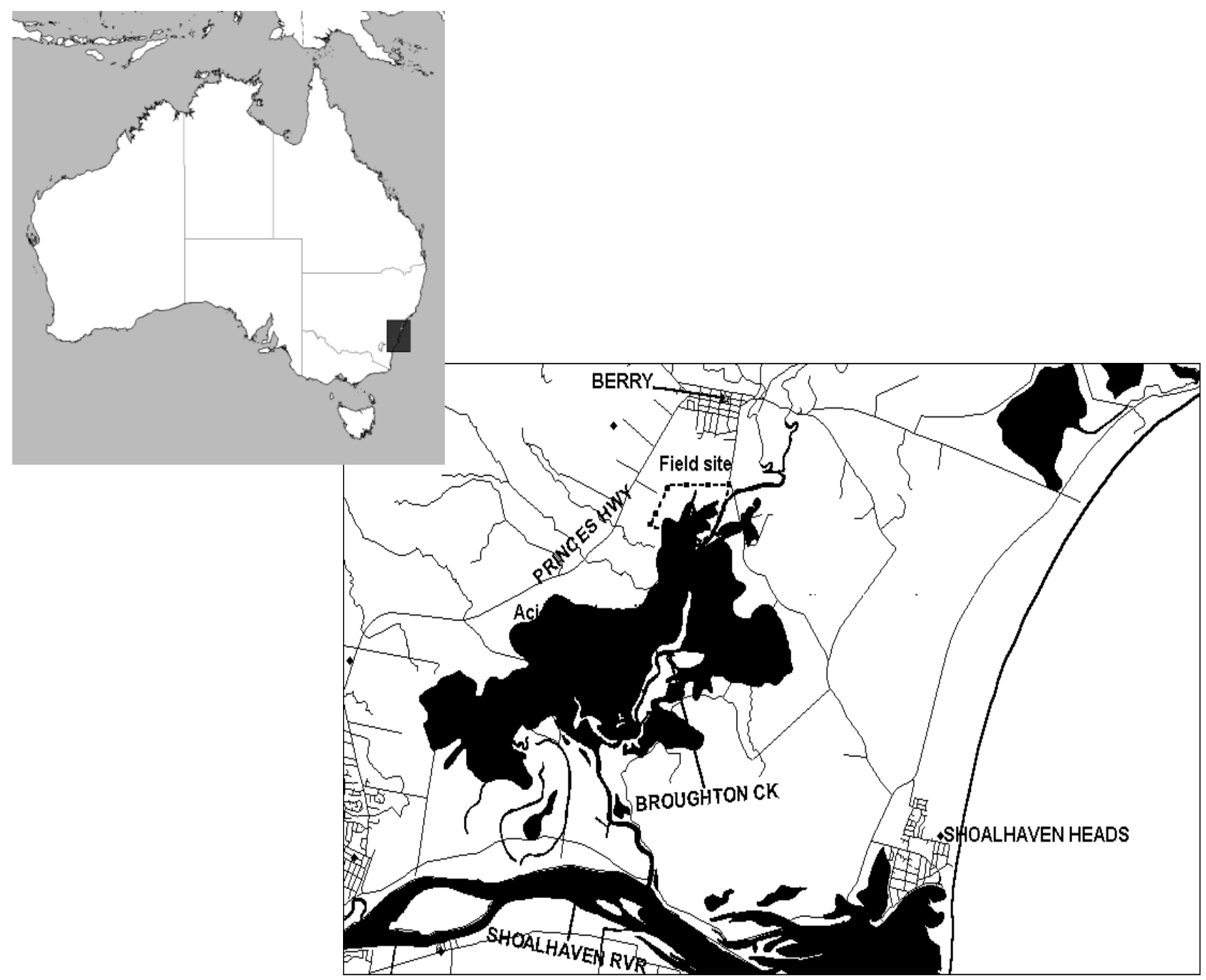

Fig. 2. Map of study location, south of Sydney, NSW, Australia. The shaded section is the area affected by acid sulphate soils.

Three V-notch weirs were installed in the flood mitigation drains at the study site at $0.1,0.4$, and $0.6 \mathrm{~m}$ above the pyritic layer. The aim was to determine if elevating the drain water level would stop fresh pyrite oxidation and sufficiently neutralize the remnant acidity. The groundwater elevation and composition were monitored at 59 locations for a period of 440 days pre-weir installation and 373 days post-weir installation.

During the pre-weir monitoring period, the study site experienced two short duration floods and one drought, and the water table fell below the potential acid sulphate soil (PASS) layer for over 100 days at most locations. However, after the weirs were installed, the groundwater table was maintained above the PASS layer at most locations for the entire monitoring period. The drain water level also increased after the weirs were installed, often by more than $0.3 \mathrm{~m}$. The higher drain elevations reduced groundwater drawdown close to the drains and established low hydraulic gradients, although the effect was less pronounced with distance from the drain (Fig. 3).
At the beginning of the pre-weir monitoring period, the groundwater $\mathrm{pH}$ was less than 3.5 , but the $\mathrm{pH}$ quickly increased due to dilution by two flooding events and rose above 5 during the drought. At the breaking of the drought, however, the $\mathrm{pH}$ fell to 2.5-3.5. The installation of the weirs reduced the rate of discharge of acidic oxidation products from the groundwater to the drain, but did not substantially improve the quality of the groundwater or soil. The weirs require maintenance every six months to clear away sediments that accumulate near the weir and to remove weeds and other debris from the drain, up to $100 \mathrm{~m}$ either side of the weir.

\section{Numerical modelling of groundwater regimes}

The groundwater regimes were simulated using the FEMWATER finite element software. The computational discretization used by FEMWATER is a threedimensional mesh. The elements used in the simulation are triangular prisms, each with six nodes, as shown in 
(a)

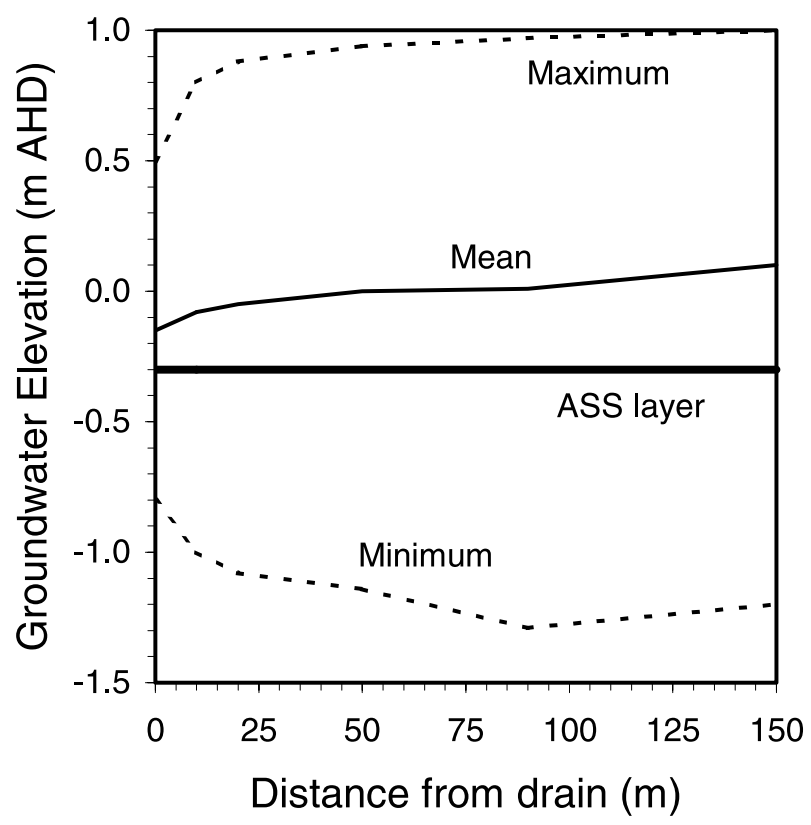

(b)

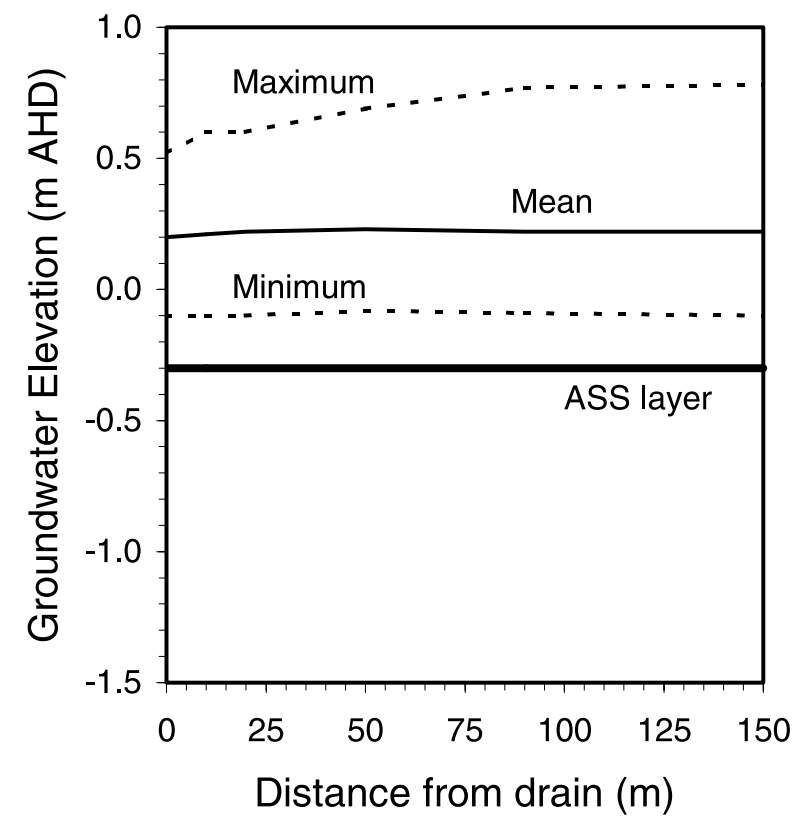

Fig. 3. Average groundwater elevation (a) before and (b) after weir installation, with the maximum and minimum groundwater elevation dashed.

Figure $4 \mathrm{a}$ in both plan and elevation. At all six nodes, a non-linear flow equation is solved by the Galerkin finite element method. Further properties of the elements, nodes, and solution procedures are described by Blunden (2000). Soil physical parameters used to define the material properties in FEMWATER were determined from saturated hydraulic conductivity and moisture characteristic data. Cross-sections of the head boundary conditions at the drain-soil interface for the drain and weir simulations are depicted in Figure 5.

The modelling period included a wet period with groundwater close to the surface, as well as a prolonged dry period that resulted in groundwater falling below the ASS layer. The FEMWATER-modelled groundwater elevations are in good agreement with the observed groundwater elevation data collected over a 12-month period pre-weir (Fig. 4b), indicating that this numerical analysis is able to adequately simulate the groundwater hydrology of the study site. The finite element simulation indicated that a substantial increase in the groundwater level was achieved at $10 \mathrm{~m}$ and $90 \mathrm{~m}$ distance from the drain by maintaining the water level of the drain at $-0.5 \mathrm{~m}$ AHD using a weir. Even during the worst part of the drought period when groundwater levels fell well below the elevation of the ASS layer, maintenance of the drain water level at $-0.5 \mathrm{~m}$ AHD resulted in the groundwater at 10 and $90 \mathrm{~m}$ from the drain being $0.5 \mathrm{~m}$ and $0.4 \mathrm{~m}$ respectively higher than under the existing drained conditions (Blunden \& Indraratna 2000).

\section{Numerical modelling of pyrite oxidation}

To model pyrite oxidation and water management options, it is important to understand the groundwater regime and its subsequent impact on the oxidation of pyrite in two or three dimensions. SMASS is a onedimensional model, and as such, is of limited use in assessing the implications of water management strategies, particularly where drawdown from large drains or evapotranspiration from crops is expected to result in variable groundwater elevation across the site. To overcome this shortcoming, a pyrite oxidation model with the output of three-dimensional (3D) FEMWATER simulations was used. The detailed theoretical developments of the pyrite oxidation model were presented earlier by Blunden \& Indraratna (2001). An ACID3D model was used to calculate the amount of pyrite in the acid sulphate soil with a macropore/matrix structure. The concentration of pyrite in the sulphidic soil was measured at three depths at $90 \mathrm{~m}$ from the drain and the pyrite concentration computed by the model corresponds well with the measured concentration (Fig. 6). The simulation showed that the weir caused a substantial increase in the groundwater level and a substantial reduction in the amount of sulphate produced from the oxidation of pyrite. The reduction in sulphate production from pyrite oxidation can be attributed to a high level of water saturation in different parts of the soil profile. The nearly saturated soil layers act as an oxygen barrier, which reduces the amount 
(a)

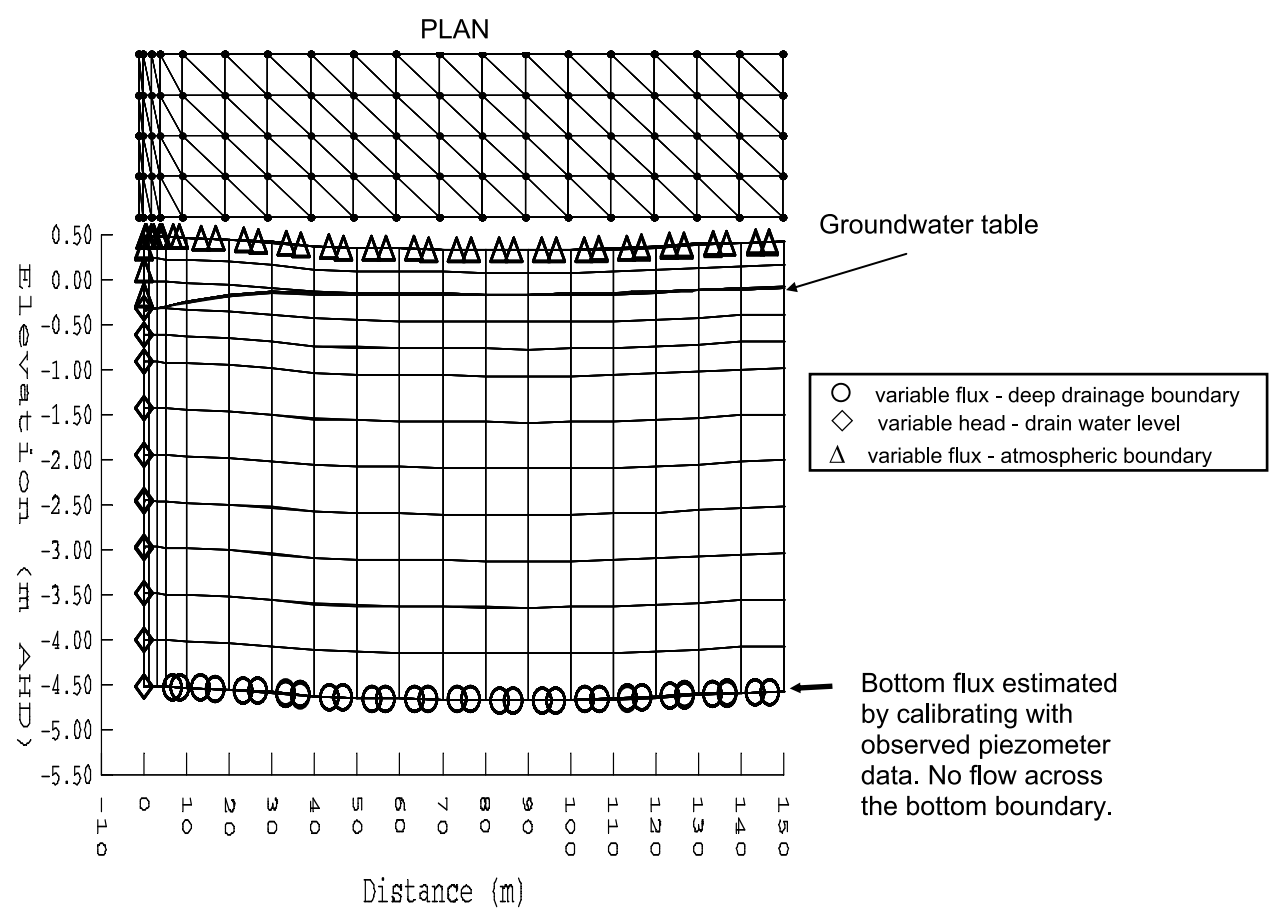

(b)

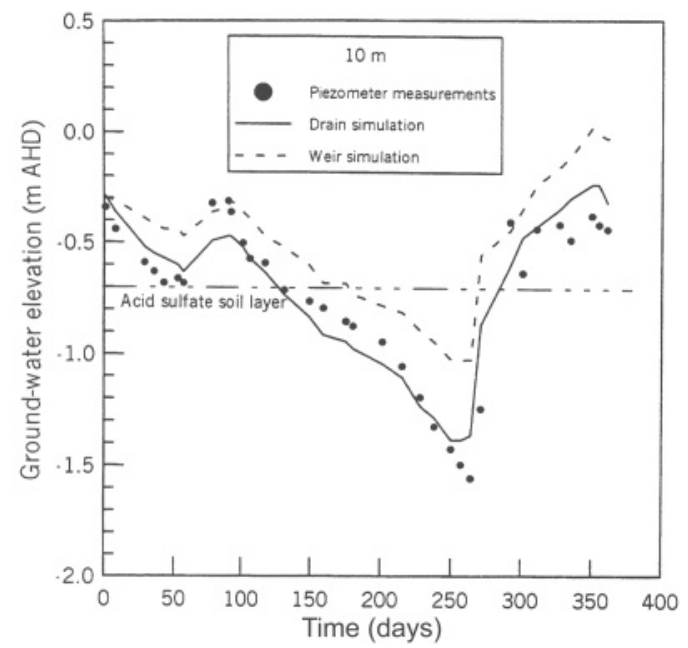

Fig. 4. (a) Typical finite element mesh showing the plan and elevation of the 3D-triangular elements. (b) Measured and predicted groundwater levels at $10 \mathrm{~m}$ from the drain (adapted from Blunden \& Indraratna 2001).

of oxygen that can be transported to the pyritic sediments.

The groundwater and soil remained acidic following weir installation indicating that biotic oxidation of pyrite may be still occurring beneath the groundwater table by iron and sulphur oxidizing bacteria. The bacteria enhance pyrite oxidation through the reduction of $\mathrm{Fe}^{3+}$ at $\mathrm{pH}<4$, as shown in the following equation (Willett et al. 1992):

$$
\mathrm{FeS}_{2}+14 \mathrm{Fe}^{3+}+8 \mathrm{H}_{2} \mathrm{O} \rightarrow 15 \mathrm{Fe}^{2+}+2 \mathrm{SO}_{4}{ }^{2-}+16 \mathrm{H}^{+}
$$

\section{Tidal buffering using modified floodgates}

Following the installation of V-notch weirs, the modification of floodgates to allow tidal ingress and hence buffering of the acidity by the carbonate/bicarbonate in seawater was investigated. The floodgates are installed on productive agricultural pastures and any floodgate modifications would involve changing the hydrodynamics of the study drain, therefore several environmental and hydraulic concerns were addressed prior to 

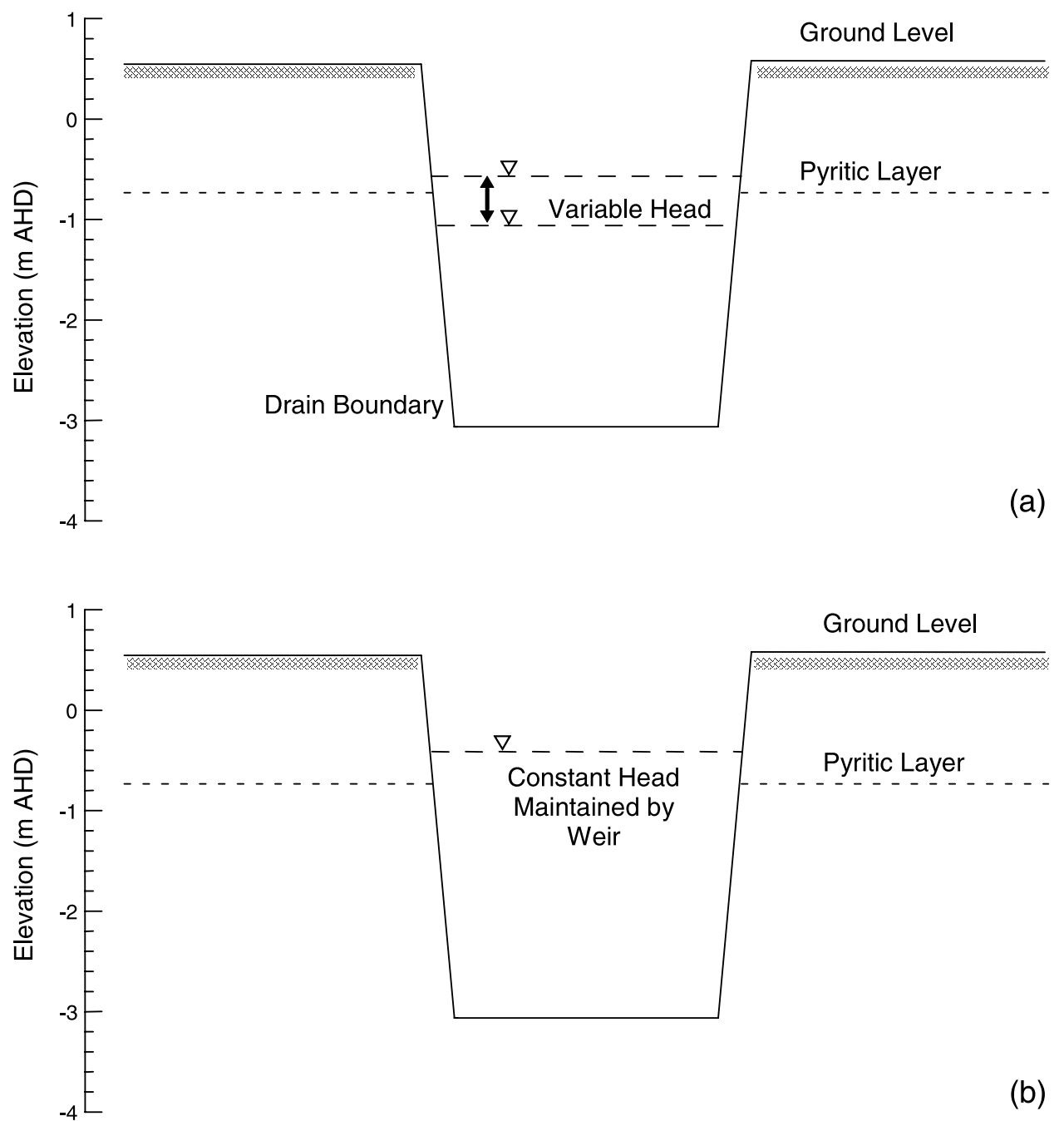

Fig. 5. Simulated head boundaries for drain water levels: (a) variable head in the absence of weir; (b) V-notch weir simulation using constant head.

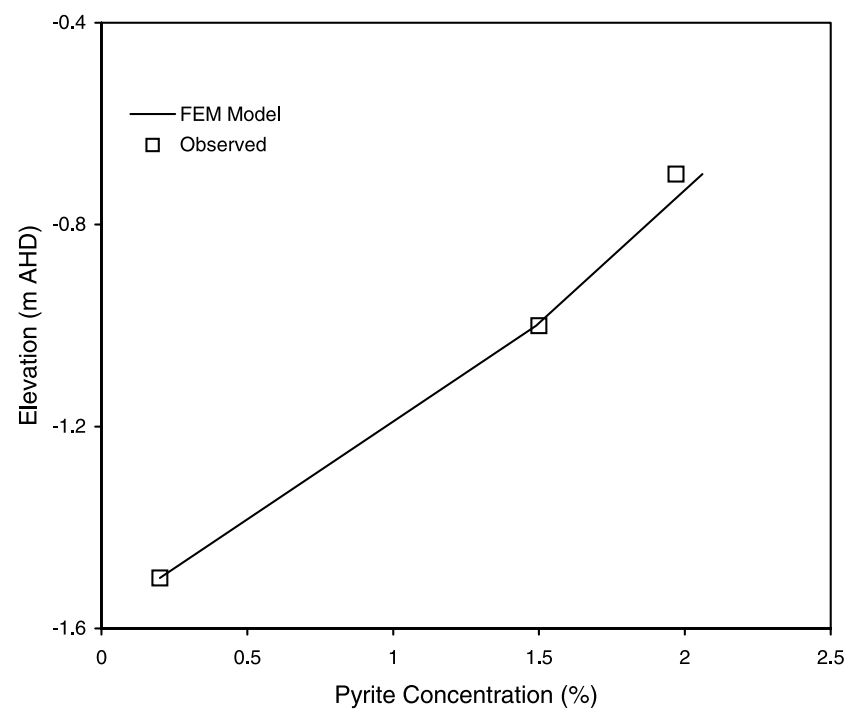

Fig. 6. Simulated and measured pyrite concentrations in soil at three elevations. commencing civil works. The concerns include: (i) predicting the potential change in drain water quality due to tidal buffering, (ii) optimizing the drain water level with tidal influx without overtopping the levee bank or reducing agricultural productivity, and (iii) studying the impact of increased salinity on the subsoil matrix.

\section{Numerical modelling of drain water composition}

In order to satisfy the above considerations, tidal restoration in a flood mitigation drain was simulated using a digital terrain map (developed using airborne laser scanning data), geographic information tools, and measured water levels to predict drain overtopping due to tidal variations. The GIS (ArcGIS, version 8.1) simulations indicated that the primary drainage network could safely contain full tidal flushing. Next, changes in drain water quality were simulated using an ion-specific program code written within PHREEQC, which was chosen 
(a)
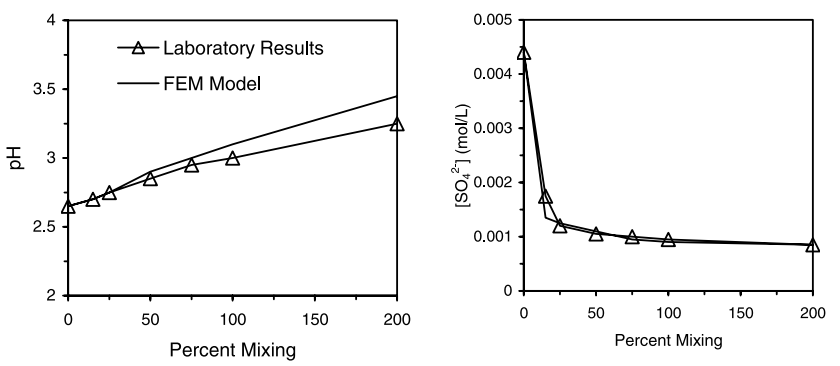

(b)
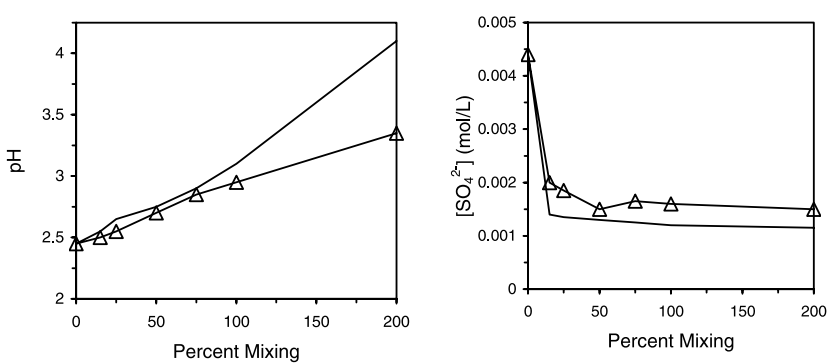

Fig. 7. Simulations from PHREEQC compared to laboratory results for mixing of drain water with: (a) low ionic strength samples; and (b) high ionic strength samples from Broughton Creek.

due to its ability to simulate chemical speciation and mixing over varying salinities. The program was written and incorporated into the 1D ion association aqueous model then modified, calibrated, and applied to evaluate the mixing of alkaline creek water of varying ionic strengths with aluminium- and iron-rich acidic drain water (Glamore \& Indraratna 2004). Three assumptions were made for the mixing program: (i) creek water entering the drain completely mixes with acidic drain water, (ii) bicarbonate concentrations are equally distributed throughout the drain, and (iii) reactions reach equilibrium over the simulated timescales of mixing and discharge.

The main inputs to the mixing program were elemental concentrations and electrical conductivity. These variables were determined using samples of brackish river water, rain-diluted river water, fresh creek water and acidic drain water, which were analysed for major cations, $\mathrm{Cl}^{-}$and $\mathrm{SO}_{4}{ }^{2-}, \mathrm{pH}$, alkalinity, and EC. The program was developed to simulate mixing in $10 \%$ intervals, until twice as much alkaline water had been added compared to acidic water (i.e. $200 \%$ ). The model agrees well with the laboratory measurements of mixing of the four types of water samples (Fig. 7) for both low and high ionic strength waters. Both the simulations and the laboratory results indicate that drain water quality improved with mixing.

\section{Tidal restoration}

Based on the numerical simulations, two modified twoway floodgates were installed: (a) a winch that lifts the floodgate vertically, controlling the amount of water permitted upstream of the floodgate, and (b) an automated 'Smart Gate' system that permits tidal flushing based on real-time water quality parameters. The restoration of tidal flushing within the study drain triggered immediate improvements in drain water quality (Fig. 8). Before modifying the floodgates, the drain water was consistently acidic (average $\mathrm{pH}$ 4.6) but following the 'Smart Gate' installation, the drain water $\mathrm{pH}$ increased to 6.04 and aluminium and iron concentrations decreased by more than $50 \%$. The predicted $\mathrm{pH}$ and ion

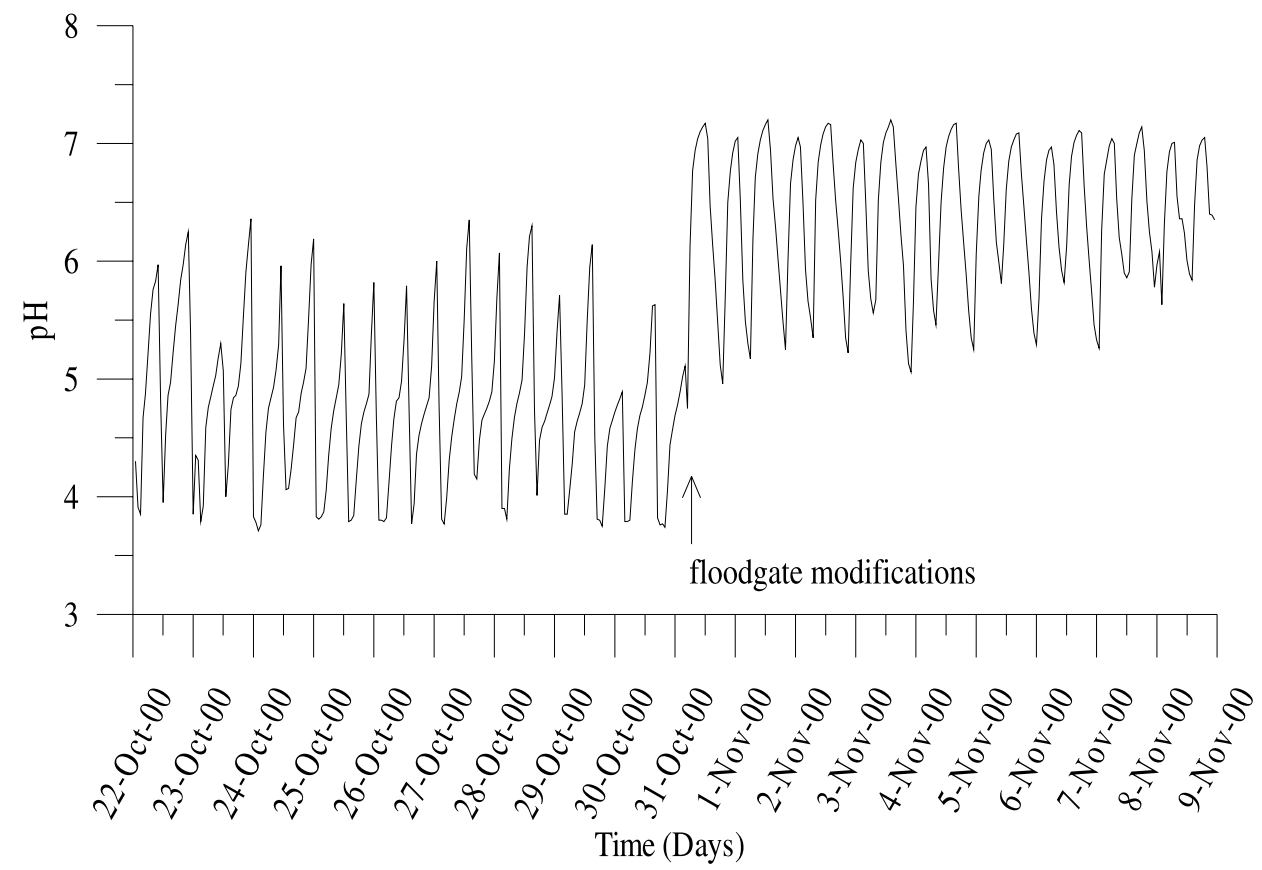

Fig. 8. Drain water $\mathrm{pH}$ readings collected immediately before and after floodgate modifications. 
Table 1. Water quality of drain before and after floodgate modifications compared to predicted values.

\begin{tabular}{lccc}
\hline & $\mathrm{pH}$ & $\begin{array}{c}\mathrm{Al}^{3+} \\
(\mathrm{ppm})\end{array}$ & $\begin{array}{c}\mathrm{Fe}^{\text {total }} \\
(\mathrm{ppm})\end{array}$ \\
\hline $\begin{array}{l}\text { Mean drain composition } \\
\text { (Pre-modification) }\end{array}$ & 4.32 & 11.33 & 23.07 \\
$\begin{array}{l}\text { Mean drain composition } \\
\text { (Post-modification) }\end{array}$ & 6.04 & 4.38 & 10.33 \\
$\begin{array}{l}\text { Change (\%) } \\
\text { Predicted drain composition } \\
\text { (Post-modification) }\end{array}$ & 6.02 & 4.04 & 12.40 \\
\hline
\end{tabular}

concentration data agree well with the experimentally determined results (Table 1).

The mean drain water quality significantly improved after floodgate modifications were performed. The drain water quality displayed diurnal tidal variations (Fig. 8). However, in addition to diurnal tidal effects, fluctuations also occurred with changing climatic conditions (Fig. 9); after large rainfall events, the $\mathrm{pH}$ dropped. Large rainfall events (i) flushed neutralizing agents from the estuary, (ii) recharged the groundwater table, and (iii) enhanced groundwater seepage, leading to decreases in drain $\mathrm{pH}$. In contrast to pre-modification results during dry conditions when the drain water was extremely acidic, dry periods following floodgate modifications were characterized by $\mathrm{pH}$-neutral conditions due to the restoration of tidal flushing within the drain and increased tidal buffering.

Tidal restoration within the flood mitigation drain caused saline contaminants to intrude into the soil matrix through hydrodynamic dispersion and advection. Increases in soil salinity were limited to samples taken close to the drain and were not in excess of ANZECC (1992) guidelines. The saline intrusion plume was characterized by a saline wedge bounded by a transition zone, which was limited to $8 \mathrm{~m}$ perpendicular from the drain and remained predominately $2 \mathrm{~m}$ below the ground surface. The transient nature of the saline wedge and the limited contamination plume illustrate that agricultural productivity on the surface should not be affected by tidal flushing within the drain.

Extensive field and laboratory measurements were conducted before and after floodgate modifications, such as baseline monitoring of groundwater elevation, $\mathrm{pH}$ and EC using dataloggers, chemical analysis of soil samples for salinity and nutrient contents, and analysis of groundwater collected from different levels in the soil. These tests indicated that saline intrusion did not increase the quantity of pyrite oxidation products, which is in contrast to the findings of Portnoy \& Giblin (1997), who report that saline intrusion may increase aluminium and iron levels. Within the saline transition zone, $\mathrm{pH}$ increased due to the neutralization of $\mathrm{H}^{+}$ions by surface water bicarbonates (Table 2), while the redox potential decreased due to the decomposition of organic matter

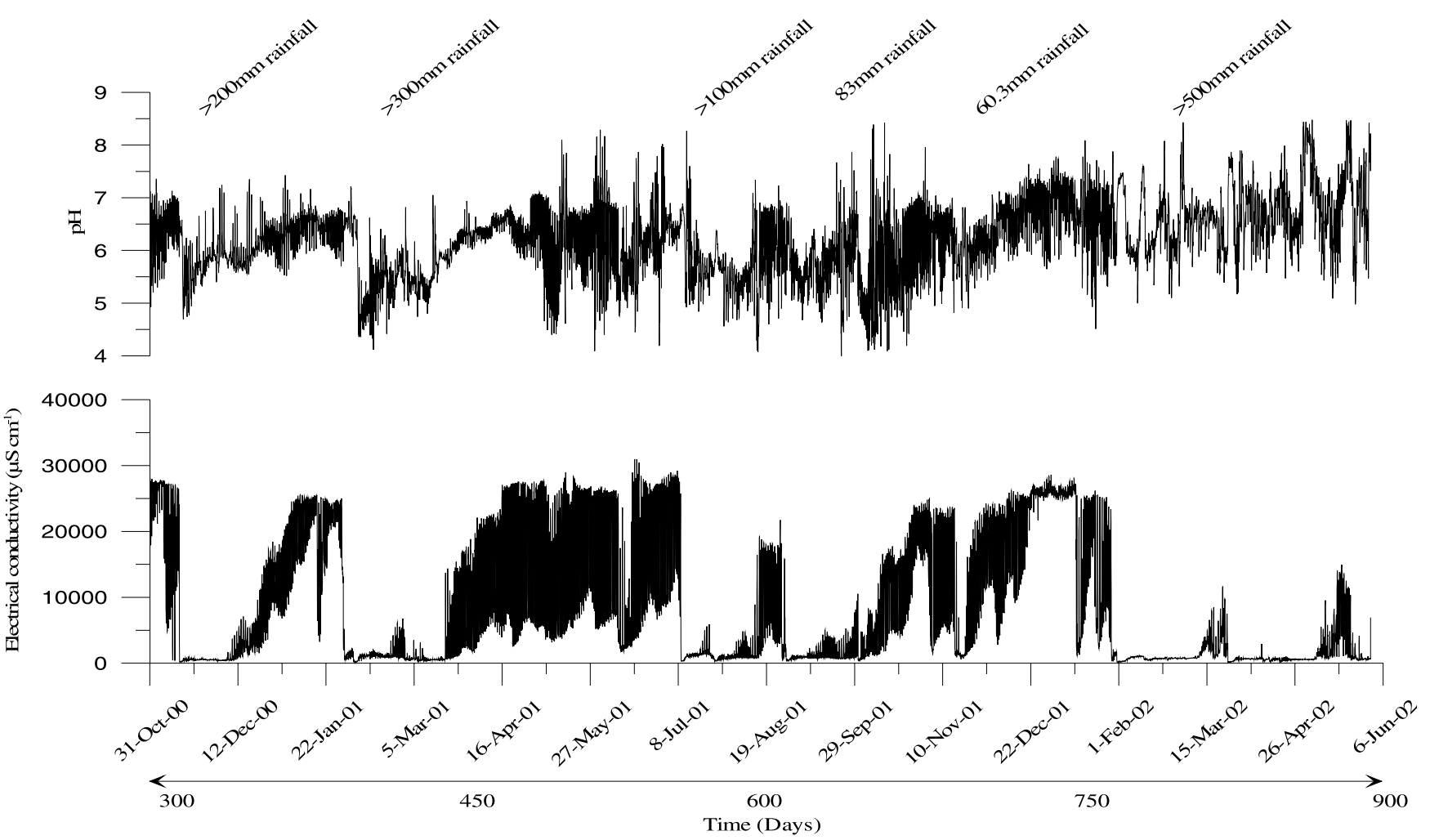

Fig. 9. Fluctuations in $\mathrm{pH}$ and EC caused by rainfall events, as recorded by a continuous data logger located $1 \mathrm{~m}$ upstream of the modified floodgate. 
Table 2. Groundwater composition adjacent to and distant from the drain.

\begin{tabular}{lcc}
\hline Parameter & Adjacent to drain & Distant from drain \\
\hline $\mathrm{pH}$ & 5.6 & 3.0 \\
Redox potential $(\mathrm{mV})$ & 70 & 230 \\
Aluminium $(\mathrm{mg} / \mathrm{l})$ & 20 & 45 \\
Iron $(\mathrm{mg} / \mathrm{l})$ & 20 & 40 \\
Sulphate $(\mathrm{mg} / \mathrm{l})$ & 30 & 45 \\
\hline
\end{tabular}

and the inability of oxygen to remain in solution under saline conditions. The increased $\mathrm{pH}$ and reduced redox levels caused a decrease in the soluble aluminium, iron and sulphate concentrations (Table 2).

\section{Numerical modelling of saline intrusion}

To determine the impact of saline intrusion over varying climatic and geophysical conditions, a 3D finite element model was developed. The primary aim of the model was to determine the extent and magnitude of saline intrusion in a worst-case scenario and in response to rainfall events. The coupled flow and transport of saline contaminants into the soil matrix is simulated using a 3D finite element model for variably saturated media, namely, FEMWATER. Details of the finite element formulation and mesh properties are given by Glamore (2003). The model requires a broad range of initialization parameters including geotechnical, environmental, climatic, topographic, and hydraulic information. The climatic and drain water conditions collected during this study were used as inputs for the surface and drain water boundary conditions. Similarly, the physical soil properties were sourced from extensive field tests. Once the model was initialized and calibrated, several environmental scenarios were simulated to analyse the saline intrusion process.

The initialized numerical model was run to simulate coupled groundwater flow and chemical species transport in response to tidal forcing of saline contaminants along the drain boundary. A 12-week trial, which incorporated wet and dry periods (i.e. high saline thresholds), was used to calibrate the model. After calibration, the model was used to simulate intense saline intrusion periods (i.e. worst-case scenarios) and to determine the influence of natural recharge on salt export.

Model calibration The model simulations of groundwater flow agreed with field data. The results show that the phreatic zone fluctuated widely at $1 \mathrm{~m}$ from the drain, and tidal forcing dissipated with distance $(10 \mathrm{~m}$ inland). The fluctuations in the saturated zone were primarily associated with daily tidal changes, whereas groundwater recharge was controlled by rainfall. Importantly, the strong agreement between field and calculated results indicated that the constructed finite element model could simulate groundwater flow throughout the soil matrix to an acceptable accuracy.

A graphical representation of the finite element simulation (Fig. 10) depicts the ingress and flushing of a saline intrusion front in response to changing climatic and boundary conditions. Figure 10a shows a typical 3D mesh constructed using FEMWATER finite element code. After one hour, salts are solely concentrated on the drain boundary, but as drying conditions persist (1000 hours) saline contaminants intrude into the subsurface soil matrix in a wedge-like manner. The transitional front reaches its maximum intrusion distance after the 1500th hour, and, after 2000 hours and $83 \mathrm{~mm}$ of rainfall, the majority of saline contaminants were flushed from the soil. These plots not only illustrate the removal of the saline wedge in response to rainfall, but also show that the wedge is a transitional zone between highly saline concentrations at the drain boundary and low ionic groundwater, and not a sharp interface. The simulation also shows that while rainfall triggers groundwater flushing, it does not completely remove the contaminants. In fact, after rainfall an isolated saline area develops within the soil matrix approximately 1-2 $\mathrm{m}$ inland from the drain. Importantly, these results prove that this area does not represent a significant threat to agricultural activity, which was a concern of environmental organizations and local government.

Maximum saline intrusion Based on the above findings, a series of simulations were devised to gauge the extent and magnitude of saline intrusion in response to extreme climatic factors. In order to simulate these conditions, the 12-week period was modified so that (i) drain water salinity was maintained at 20 parts per thousand (ppt), (ii) rainfall was removed from the surface boundary, and (iii) a constant evapotranspiration rate, based on longterm field site averages $\left(2.21 \mathrm{~mm} \mathrm{day}^{-1}\right)$, was imposed on the surface boundary. The dry conditions represented within this simulation were designed to illustrate the influence of tidal forcing on the groundwater regime during a worst-case scenario.

The numerical predictions (Fig. 11) illustrate that saline intrusion is not a significant concern even under extreme conditions. Initially the groundwater salinity is low throughout the soil matrix, but under continued dry conditions, saline seepage occurs in a subsurface wedgeshaped intrusion front (1000 to 1500 hours). The wedge continues to intrude into the soil matrix, but even after 2000 hours the majority of contaminants are restricted to less than $6 \mathrm{~m}$ from the drain. The salinity concentrations beyond $6 \mathrm{~m}$ comply with ANZECC guidelines and do not pose a risk to agricultural productivity. When the temperate climate and year-round average rainfall of the region is taken into consideration, these findings suggest that even under extreme conditions, saline intrusion should not be a concern in tidally restored flood mitigation drains in southeastern NSW. 
(a)

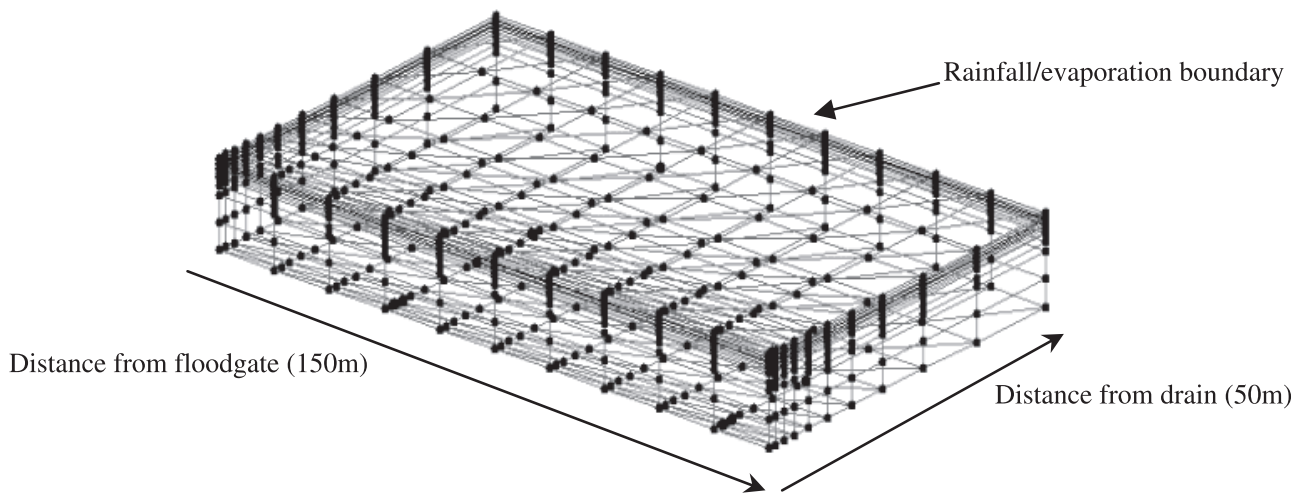

(b)
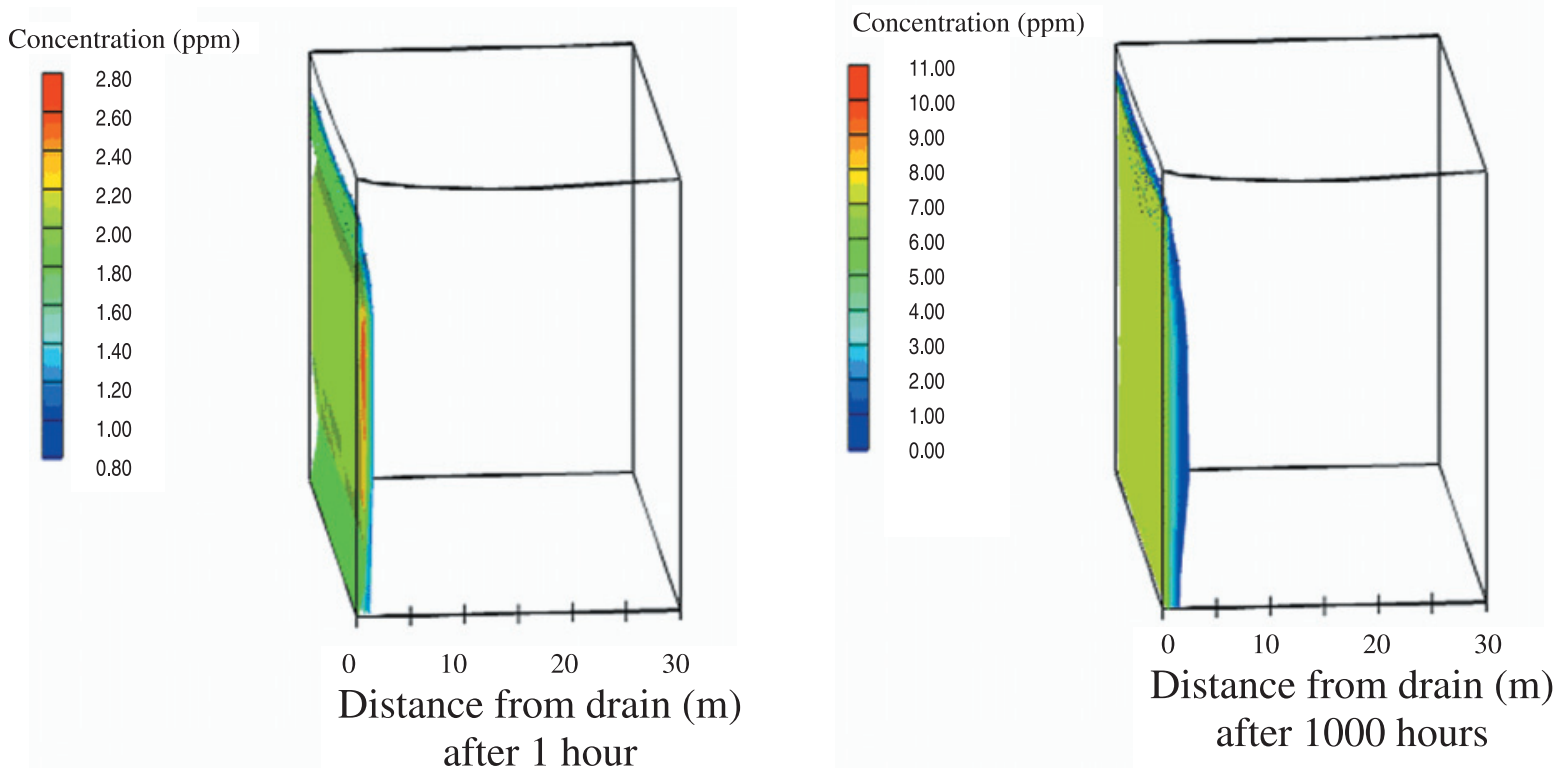

Concentration (ppm)

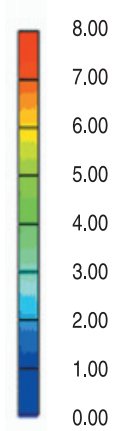

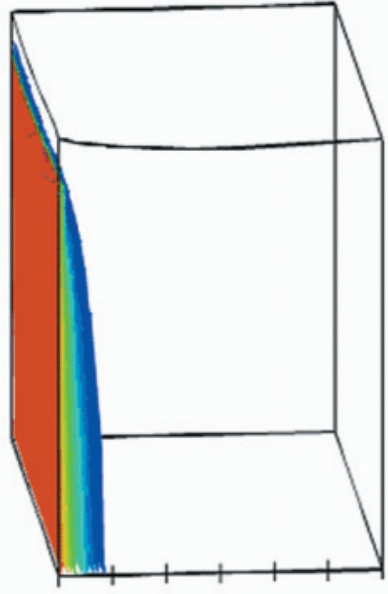

20

Concentration (ppm)

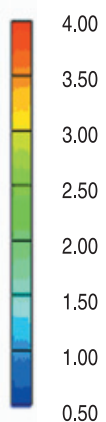

Distance from drain (m) after 1500 hours
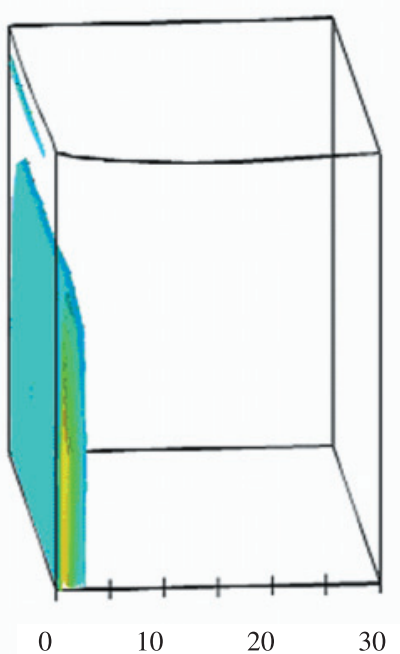

Distance from drain (m) after 2000 hours

Fig. 10. (a) Typical finite element mesh. (b) Saline intrusion within the finite element mesh during calibration at 1, 1000, 1500 and 2000 hours. The plot height is $5 \mathrm{~m}$. 
Concentration (ppm)

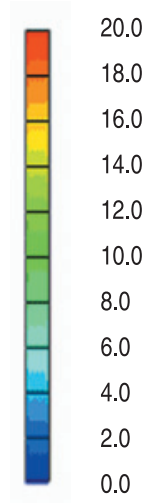

Concentration (ppm)

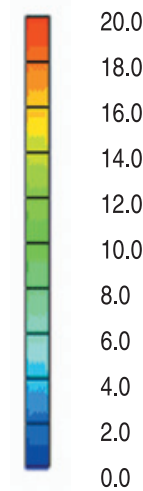

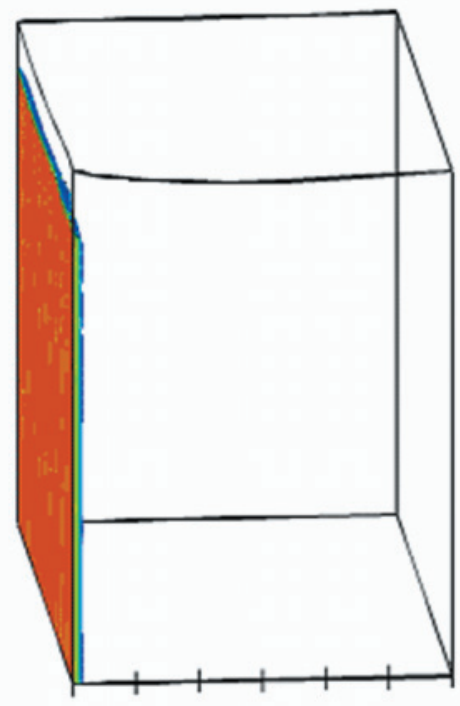

$\begin{array}{llll}0 & 10 & 20 & 30\end{array}$

Distance from drain (m) after 1 hour

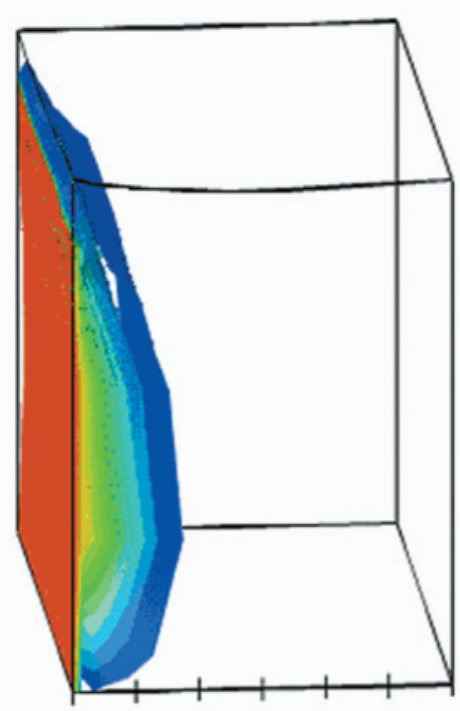

0

10

20

30

Distance from drain $(\mathrm{m})$ after 1500 hours

\section{Concentration (ppm)}

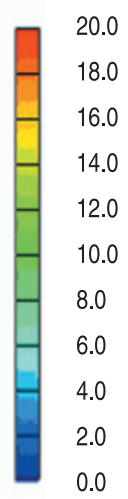

Concentration (ppm)

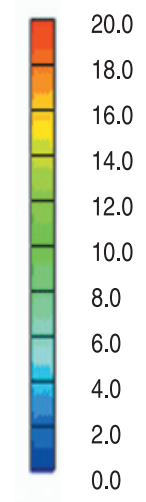

$\stackrel{0}{0} \stackrel{10}{20} \stackrel{30}{\text { Distance from drain (m) }}$ after 1000 hours

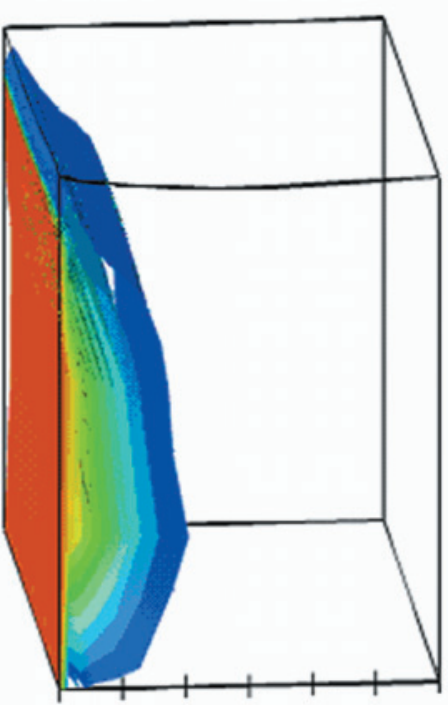

$0 \quad 10 \stackrel{20}{20}{ }^{30}$
Distance from drain (m)
after 2000 hours

Fig. 11. Calculated maximum saline intrusion under extreme climatic conditions after 1, 500, 1000 and 2000 hours. The plot height is $5 \mathrm{~m}$.

\section{Conclusions}

In conclusion, the elevation of the groundwater table can be manipulated by the installation of weirs in flood mitigation drains. Groundwater table elevations measured at the Berry field site, as well as groundwater simulation modelling outcomes showed that significant improvements can be made to minimize the volume of exposed pyritic soil by decreasing groundwater drawdown close to the drains. During the pre-weir monitoring period, the elevation of the groundwater table was controlled by groundwater drawdown towards the drains, evapotranspiration, and rainfall. After significant rainfall, the groundwater table rose through the 
zone where pyrite oxidation had occurred during the preceding dry period, entraining the pyrite oxidation products and often leading to extremely acidic groundwater conditions ( $\mathrm{pH} 2-3$ ). The installation of weirs led to higher groundwater levels and minimized the production of 'new' acid from the oxidation of pyrite by oxygen. In addition, maintenance of higher drain water levels caused lower groundwater hydraulic gradients towards the drain, thus reducing the rate of acid discharge to the drain.

The elevated groundwater levels did not improve long-term groundwater quality. The nature of the 'stored' acid in the soil profile previously caused by pyrite oxidation kept the groundwater $\mathrm{pH}$ maintained at 3.5-4.0. In addition, the concentration of dissolved aluminium and iron remained high. Also, in areas where the groundwater table is already near the surface, the risk of flooding is increased by the use of V-notch weirs. An alternative is the automated self-regulating tilting weir that was not discussed within the scope of this paper.

Prior to floodgate modifications, extensive finite element and geochemical modelling was performed to determine the impact of tidal restoration on the drains. Two innovative floodgates were designed. The first allowed manual vertical adjustment of the floodgate flap and permitted full tidal intrusion within the drain while maintaining control under varied flow conditions. The second model automatically adjusts the gate to control tidal ingress within the drain based on real-time upstream chemical and hydraulic parameters and remote telemetry access. Following installation of the redesigned floodgates and the establishment of full tidal flushing within the primary drain, water quality significantly improved, $\mathrm{pH}$ increased by two orders of magnitude and dissolved aluminium and iron decreased by more than $50 \%$.

An extensive analysis of the phreatic zone and finite element modelling was also undertaken to determine the extent and distribution of the saline intrusion front due to tidal restoration. Groundwater measurements showed that increased drain water elevations raised the surface of the phreatic zone above the pyrite zone, but tidal fluctuation increased groundwater variance. Tidal forcing on the phreatic zone and saline intrusion was limited to within $8 \mathrm{~m}$ of the drain. In addition, both field studies and finite element analysis indicated that rainfall recharged the groundwater table and flushed saline contaminants into the creek. Geochemical field investigations also showed that saline intrusion increased groundwater $\mathrm{pH}$, reduced redox potential, and decreased the dissolved aluminium concentrations. Extensive field data as well as comprehensive finite element analysis suggested that even under extreme conditions, tidal restorations within the flood mitigation drain would not adversely affect the soil chemistry at the study site.
Acknowledgements. The authors wish to thank Bob Rowlan, Anand Tularam, Shoalhaven City Council, and local landholders for their support and technical assistance.

\section{References}

ANZECC 1992. Australian Water Quality Guidelines for Fresh and Marine Waters. Australian and New Zealand Environment Conservation Council, Canberra.

Blunden, B. 2000. Management of Acid Sulfate Soils by Groundwater Manipulation. PhD Thesis. Faculty of Engineering, University of Wollongong, Wollongong.

Blunden, B.G. \& IndraRatna, B. 2000. Evaluation of surface and groundwater management strategies for drained sulfidic soil using numerical simulation models. Australian Journal of Soil Research, 38, 569-590.

Blunden, B. \& Indraratna, B. 2001. Pyrite oxidation model for assessing ground-water management strategies in acid sulfate soils. Journal of Geotechnical and Geoenvironmental Engineering, 127 (2), 146-157.

Blunden, B., Indraratna, B. \& Nethery, A. 1997. Effect of groundwater table on acid sulphate soil remediation. In: Bouazza, A., Kodikara, J. \& Parker, R. (eds) GeoEnvironment 97. Balkema, Rotterdam, 549-554.

Dick, T.M. \& OsunkoyA, O.O. 2000. Influence of tidal restriction floodgates on decomposition of mangrove litter. Aquatic Botany, 68 (3), 273-280.

Glamore, W. 2003. Evaluation and Analysis of Acid Sulphate Soil Impacts via Tidal Restoration. PhD Thesis. Faculty of Engineering, University of Wollongong.

Glamore, W. \& Indraratna, B. 2001. The impact of floodgate modifications on water quality in acid sulphate soil terrains. In: McGrath, B., Gourlay, M. \& Nielson, P. (eds) 15th Australasian Coastal and Ocean Engineering Conference Proceedings. The Institute of Engineers, Sydney, 265-270.

Glamore, W. \& Indraratna, B. 2004. A two-stage decision support tool for restoring tidal flows to flood mitigation drains affected by acid sulphate soil: case study of Broughton Creek Floodplain, New South Wales, Australia. Australian Journal of Soil Science, 42, 639-648.

IndRARATNA, B. \& BLUNDEN, B. 1999. Nature and properties of acid sulphate soils in drained coastal lowland in NSW. Australian Geomechanics Journal, 34 (1), 61-78.

Indraratna, B., Tularam, G.A. \& Blunden, B. 2001. Reducing the impact of acid sulphate soils at a site in Shoalhaven Floodplain of New South Wales, Australia. Quarterly Journal of Engineering Geology and Hydrogeology, 34, 333-346.

Indraratna, B., Glamore, W.C. \& Tularam, G.A. 2002. The effects of tidal buffering on acid sulphate soil environments in coastal areas of New South Wales. Geotechnical and Geological Engineering, 20, 181-199.

Johnston, S.G., Slavich, P. \& Hirst, P. 2002. Floodgate and drainage system management: opportunities and limitations. An acid export perspective. In: MaCDonald, B.C.T, KeEne, A.F., Carlin, G. \& Sullivan, L.A. (eds) Proceedings of Third International Conference on Acid Sulphate Soils, Coolangatta, Queensland. Acid Sulphate Working Group, International Union of Soil Sciences, $79-81$.

Lin, H., Richards, D., Talbot, C., Yeh, G., Cheng, J., CHENG, H. \& Jones, N. 1997. FEMWATER: A Three Dimensional Finite Element Computer Model for Simulating Density Dependent Flow and Transport in Variably Saturated Media. Technical Report, CHL-97-12. US Army. 
Pedersen, T.F. 1983. Dissolved heavy metals in a lacustrine mine tailings deposit-Buttle lake, British Columbia. Marine Pollution Bulletin, 14 (7), 249-254.

Pollard, D.A. \& Hannan, J.C. 1994. The ecological effects of structural flood mitigation works on fish habitats and fish communities in the lower Clarence River System of South-Eastern Australia. Estuaries, 17 (2), 427-461.

Portnoy, J.W. \& Giblin, A.E. 1997. Effects of historic tidal restrictions on salt marsh sediment chemistry. Biogeochemistry, 36 (3), 275-303.

Sammut, J., White, I. \& Melville, M. 1994. Stratification in acidified coastal floodplain drains. Wetlands (Australia), 13, 49-64.

Stumm, W. \& Morgan, J.J. 1996. Aquatic Chemistry 3rd. John Wiley and Sons, New York.

Sutherland, N.M., Scott, P.A. \& Morton, W.K. 1996. Field practicalities of treating acid sulfate soils. In: SMITH, R.J. \& Sмiтh, H.J. (eds) Proceedings of the 2 nd National Conference of Acid Sulfate Soils. Robert J. Smith and Associates and ASSMAC, Coffs Harbour, 221-224.

Vigneault, B., Campbell, P.G.C., Tessier, A. \& De Vitre, R. 2001. Geochemical changes in sulfidic mine tailings stored under a shallow water cover. Water Research, 35 (4), 1066-1076.

White, I., Melville, M.D., Wilson, B.P. \& Sammut, J. 1997. Reducing acidic discharges from coastal wetlands in eastern Australia. Wetlands Ecology and Management, 5 (1), 55-72.

Willett, I.R., Crockford, R.H. \& Milnes, A.R. 1992. Transformation of iron, manganese and aluminium during oxidation of a sulfidic material from an acid sulfate soil. In: SKInNER, H.C.W. \& FitzPatrick, R.W. (eds) Biomineralization Processes of Iron \& Manganese: Modern and Ancient Environments. Catena-Verlag, Cremlingen-Destedt, Germany, 287-302.

Williams, R.J. \& WATFORD, F.A. 1997. Identification of structures restricting tidal flow in New South Wales, Australia. Wetlands Ecology and Management, 5 (1), 87-97.

YANFUl, E.K. \& Verma, A. 1999. Oxidation of flooded mine tailings due to resuspension. Canadian Geotechnical Journal, 36 (5), 826-845. 